\title{
Body mass index and some biochemical parameters among valproate treated male epileptic patients
}

\author{
Othman A. Pachachi*, Imad A. Thanoon** \\ * Department of Clinical Pharmacy, College of Pharmacy, **Department of Pharmacology, \\ College of Medicine, University of Mosul.
}

(Ann. Coll. Med. Mosul 2011; 37 (1 \& 2): 114-121).

Received: $22^{\text {nd }}$ Nov 2010; Accepted: $10^{\text {th }}$ Oct 2011.

\begin{abstract}
Objective: To assess the effect of continuous valproate monotherapy (VPA) on body mass index (BMI), serum leptin, malondialdehyde (MDA) and lipid profile in male epileptic children and adult patients in comparison to healthy male controls.

Subjects, materials and methods: A case-control study design was adopted. Samples from 44 male patients (22 less than 18 years old, and 22 over than 18 years old), with primary generalized epilepsy, on continuous VPA monotherapy, for at least six months before participation in the study, were collected over the period from October 2009 to March 2010. Forty-four apparently healthy male volunteers (22 less than 18 years old, and 22 over than 18 years old) without previous history of epilepsy were recruited as controls. Serum levels of leptin, and lipid profile indices were estimated using commercially available kits and a manually prepared reagent for MDA assay. (BMI) was calculated as weight in kilograms divided by the squared height in meters.

Results: The results revealed that epileptic children and epileptic adults receiving continuous VPA monotherapy had a significantly higher BMI $(p<0.001)$, serum leptin, serum MDA and atherogenic index $(\mathrm{Al})$ and a significantly lower $(\mathrm{p}<0.001)$ serum high density lipoprotein cholesterol $(\mathrm{HDL}-\mathrm{c})$ as compared to their matched control subjects. The results also revealed insignificant difference in serum total cholesterol (TC), triglycerides (TGs) and low density lipoprotein cholesterol (LDL-C) between epileptic children and epileptic adults on VPA and their matched control subjects. Serum leptin was positively correlated with body mass index standard deviation score (BMI SDS) of epileptic children $(r=0.542 ; P<0.001)$ and duration of using VPA $(r=0.215 ; P<0.001)$ in epileptic children. The results showed insignificant difference in serum TC, TGs and LDL-c between epileptic adults on VPA and control subjects. This study also revealed that the increase in serum leptin was significantly higher $(p<0.001)$ in epileptic adults receiving continuous VPA monotherapy than in epileptic children.

Conclusion: Continuous VPA monotherapy was associated with higher BMI and serum leptin and an increase in the oxidative stress marker MDA in both male epileptic children and adults. There was no effect of VPA use on lipid profile indices in both epileptic children and adults except significant decrease in serum HDL-C and significant increase in Al.
\end{abstract}

Keywords: Valproate, male epileptic children and adult, BMI, leptin, malondialdehyde, lipid profile

$$
\begin{aligned}
& \text { الخلاصة }
\end{aligned}
$$

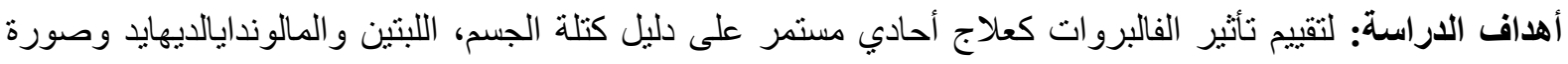

$$
\begin{aligned}
& \text { الدهون في مصل الدم عند مرضى الصر ع من الأطفال والبالغين الذكور بالمقارنة مع مجمو عة الضبط من الأصحاء. }
\end{aligned}
$$




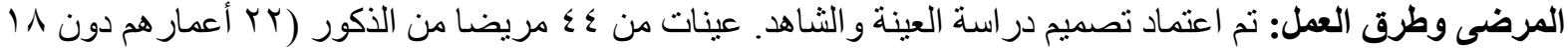

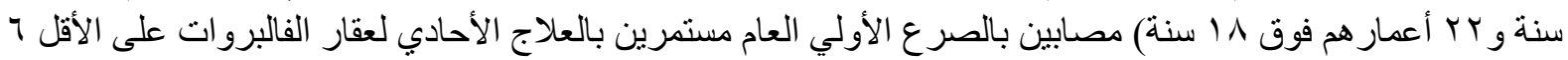

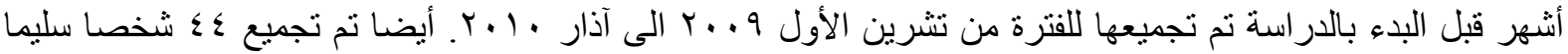

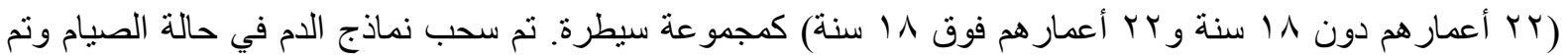

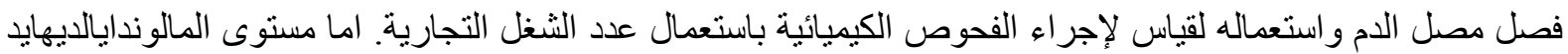

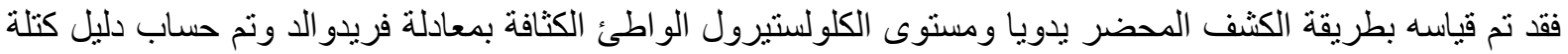

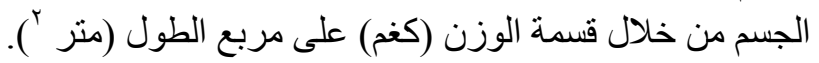

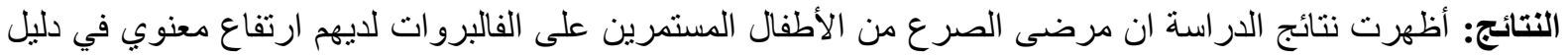

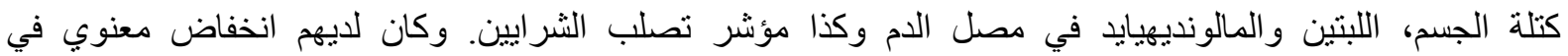
الكولستيرول عالي الكثافة ولاتوجد فروق معنوية في مستوى الكولستيرول الكلي، الدهون الثناثية، الكولستيرول واطئ الكثافة بالمقارنة مع مجمو عال الكئرة السيطرة.

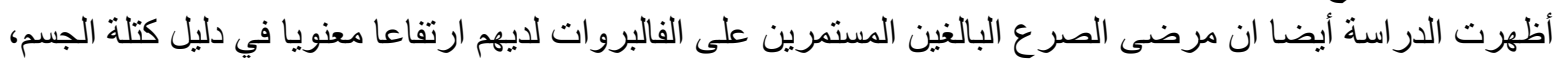

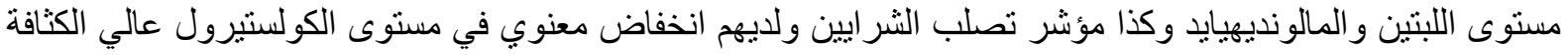

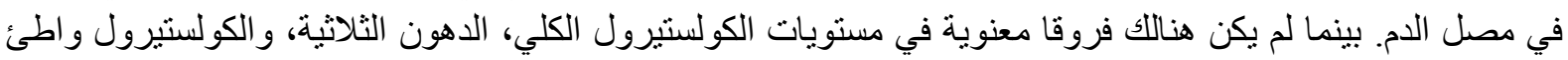
الكثافة.

الاستتتاج: استنتجت هذه الدراسة ان الاستمر ار بالعلاج الأحادي لعقار الفالبروات تر افق مع زيادة في وزن الجسم و اللبتين

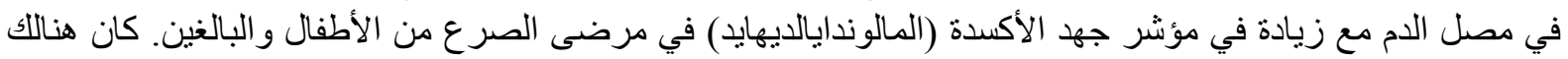

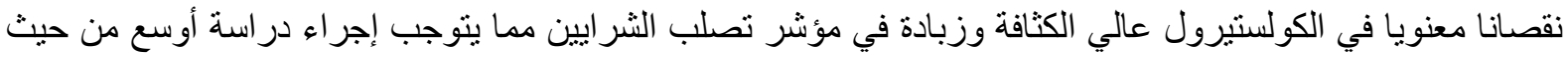

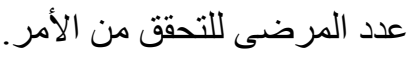
مفتاح الكلمات: الفالبروات، مرضى الصنى الصرع من الأطفال و البالغين الذكور، دلالة كتلة الجسم، اللبتين، المالوندايالديهايد،

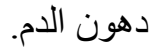

$E$ pilepsy and its medications are associated with weight changes in which weight gain is the most common and distressing particularly with Valproate (VPA) therapy ${ }^{(1,2)}$. Weight gain is a difficult problem at any age, particularly in adolescence, a period of increased awareness to body weight and image ${ }^{(3)}$. Epilepsy and its medications may alter weight homeostasis regulating process including the two main homeostatic hormones, leptin and insulin. Increased blood levels of leptin and insulin due to leptin and insulin resistances are observed in patients with epilepsy ${ }^{(4,5)}$.

The most important effect of free radicals is lipid peroxidation which results in disruption of cell membranes, and this may explain the role of oxidative stress in the etiology of seizureinduced neuronal death ${ }^{(6)}$. It has been reported that increased generation of free radicals or decreased activity of antioxidant defense systems can cause some forms of seizures and in addition can increase the risk of seizure recurrence ${ }^{(7,8)}$. Many antiepileptic drugs (AEDs) are metabolized to generate reactive metabolites with the capability of covalent binding to macromolecules as proteins or other vital biomolecules and hence eliciting systemic toxicity ${ }^{(8,9)}$. Lipid peroxidation caused by increased generation of free radicals or decreased activity of antioxidant defense systems have been suggested to be critically involved in seizure control ${ }^{(7)}$.

Many studies, mainly comprising adult patients, have provided the evidence that there is a significant influence of long-term AED therapy on total cholesterol (TC), triglycerides (TGs), high-density lipoprotein cholesterol (HDL-C), low-density lipoprotein cholesterol (LDL-C) and very low-density lipoprotein cholesterol (VLDL-c) ${ }^{(10,11)}$. VPA is not a microsomal enzyme inducer, and lipid profile during VPA treatment is controversial. Decreased, no effect, and increased levels of serum lipids have been reported in epileptic patients ${ }^{(12,13)}$. 
The aim of this study was to assess the effect of continuous VPA monotherapy on BMI, serum leptin, MDA and lipid profile in epileptic children and adults in comparison with those of healthy controls.

\section{Subjects, materials and methods Epileptic patients}

This study included 44 male patients (22 less than 18 years old with mean age $\pm S D$ of $11.26 \pm 4.41$, and 22 more than 18 years old with mean age $\pm S D$ of $30.55 \pm 6.54$ ), with primary generalized epilepsy, on continuous valproate [VPA, Depakine, Sanofi-Aventis, France] monotherapy in a mean $\pm(S D)$ dose of $386.36 \pm(99.02) \mathrm{mg} / \mathrm{d}$, for at least six months before participation in the study. These patients were referred from a private clinic over the period from October 2009 to March 2010. Patients with the following criteria were excluded from this study:

1. Patients with secondary epilepsy.

2. Patients with other neurological, medical, or psychiatric disorders.

3. Patients with rapidly progressive disorders that could alter their weight.

4. Patients with family history of body weight disorders.

\section{Control subjects}

Forty four apparently healthy male volunteers (22 less than 18 years old with mean age $\pm S D$ of $10.95 \pm 4.10$, and 22 more than 18 years old with mean age $\pm S D$ of $30.05 \pm 5.95$ ) without previous history of epilepsy were recruited as controls (with age matching to the patients group) from employees at the College of Pharmacy and Mosul College of Medicine, and from relatives who fulfilled the criteria adopted for the study. The control group was judged free of any illness by history and clinical examination. They were included in the study to compare the normal values for serum leptin, MDA and lipid profile indices.

\section{Specimens collection and analysis}

For epileptic patients, about $5 \mathrm{~mL}$ of venous blood was drawn, using a disposable syringe between 8.00 to 10.00 a.m., and after an overnight fasting. The blood was allowed to clot in a plain tube at room temperature, and then the serum was separated by centrifugation at $3000 \mathrm{rpm}$ for $10 \mathrm{~min}$., and kept frozen at $-20{ }^{\circ} \mathrm{C}$ to be analyzed later on. Samples from the control subjects were collected and processed in the same way. Serum leptin was measured by enzyme linked immunosorbent assay (ELISA) technique, using the IBL leptin ELISA Kit (Germany), which is an immunoassay for the quantitative in vitro diagnostic measurement of leptin in serum and plasma. Serum MDA levels were estimated using TBA assay method (14). Determination of serum TC and TGs concentrations was done by the enzymatic colorimetric method (Allain et al., 1974) ${ }^{(15)}$, using total cholesterol BIOLABO Kit (France). Determination of serum HDL-c concentration was done by the precipitation method (LopezVirella et al., 1977) ${ }^{(16)}$, using HDL-c BIOLABO Kit (France). Serum LDL-c concentration was calculated using Friedewald equation ${ }^{(17)}$ :

LDL-C $(\mathrm{mmol} / \mathrm{L})=\mathrm{TC}-\mathrm{HDL}-\mathrm{C}-\mathrm{TG} / 2.2$. Atherogenic index (A.I) was calculated by the following equation: $\mathrm{Al}=\mathrm{TC} / \mathrm{HDL}-\mathrm{C}^{(18)}$.

$\mathrm{BMI}$ was calculated according to the equation: $\mathrm{BMI}=$ Weight $(\mathrm{Kg}) /$ Height $\left(\mathrm{m}^{2}\right)^{(19)}$

Age and sex specific standard deviation scores (SDS) for height, weight and BMI were calculated for children according to charts developed by the National Centre for Health Statistics in collaboration with the National Centre for Chronic Disease Prevention and Health Promotion ${ }^{(20)}$.

\section{Statistical analysis}

The data were analyzed using Statistical Package for Social Sciences (SPSS) (version 11.5). Standard statistical methods were used to determine the mean and standard deviation. Unpaired t-test was used to compare the results of different biochemical parameters. Linear regression analysis [Pearson correlation coefficient $(r)$ ] was performed to identify the relationship between different biochemical parameters. p-value $\leq 0.05$ was considered to be statistically significant ${ }^{(21)}$.

\section{Results}

Tables 1 and 2 demonstrated the demographic characteristics of the epileptic patients and the control subjects respectively. 
Table 3 demonstrated the comparison of BMI SDS, serum levels of leptin, MDA and lipid profile indices between epileptic children and epileptic adults receiving continuous VPA monotherapy and their matched control subjects.

The results of this study revealed that epileptic children receiving continuous VPA monotherapy had significantly higher values for BMI, serum leptin, MDA and $\mathrm{Al}$ and a significantly lower $(p<0.001)$ serum HDL-c as compared to their matched controls, while non significant differences were demonstrated for serum TC, TGs and LDL-c. Serum leptin was positively correlated with BMI SDS of epileptic children $(r=0.542 ; P<0.001)$ and duration of usage VPA $(r=0.215 ; P<0.001)$ in epileptic children. The results of this study also revealed that epileptic adults receiving continuous VPA monotherapy had a significantly higher $(p<0.001)$ BMI, serum leptin, MDA and Al and a significantly lower $(p<0.001)$ serum HDL-c as compared to their matched controls, with insignificant difference in serum, TC, TGs and LDL-c between epileptic adults on VPA and their matched controls. This study also revealed that the increase in serum leptin was significantly higher $(p<0.001)$ in epileptic adults receiving continuous VPA monotherapy than that in epileptic children. On the other hand, there was insignificant difference in serum MDA, and lipid profile indices between epileptic children and epileptic adults receiving continuous VPA monotherapy.

Table (1): The characteristics of the epileptic patients.

\begin{tabular}{|l|c|c|}
\hline \multicolumn{1}{|c|}{$\begin{array}{c}\text { Parameters } \\
\text { Mean } \pm \text { SD }\end{array}$} & $\begin{array}{c}\text { Children }(\leq 18 \\
\text { years })(\mathrm{n}=22)\end{array}$ & $\begin{array}{c}\text { Adults }(>18 \\
\text { years })(\mathrm{n}=22)\end{array}$ \\
\hline $\begin{array}{l}\text { Patients age } \\
\text { (years) }\end{array}$ & $\begin{array}{c}6-18 \\
(11.26 \pm 4.41)\end{array}$ & $\begin{array}{c}19-44 \\
(30.55 \pm 6.54)\end{array}$ \\
\hline $\begin{array}{l}\text { Body mass } \\
\text { index (BMI) } \\
\left.\text { (kg/m }{ }^{2}\right)\end{array}$ & $27.75 \pm 4.41$ & $28.66 \pm 3.31$ \\
\hline $\begin{array}{l}\text { Duration of } \\
\text { illness (years) }\end{array}$ & $2.34 \pm 2.09$ & $5.17 \pm 6.64$ \\
\hline $\begin{array}{l}\text { Age at onset } \\
\text { (years) }\end{array}$ & $9.38 \pm 4.42$ & $25.39 \pm 9.38$ \\
\hline $\begin{array}{l}\text { Duration of } \\
\text { using VPA } \\
\text { (years) }\end{array}$ & $2.07 \pm 2.18$ & $2.86 \pm 2.98$ \\
\hline $\begin{array}{l}\text { Dose of VPA } \\
\text { (mg/day) }\end{array}$ & $386.36 \pm 99.02$ & $595.45 \pm 247.80$ \\
\hline
\end{tabular}

Table (2): The characteristics of the controls.

\begin{tabular}{|c|c|c|}
\hline $\begin{array}{c}\text { Parameters } \\
\text { Mean } \pm \text { SD }\end{array}$ & $\begin{array}{c}\text { Children }(\leq 18 \\
\text { years })(n=22)\end{array}$ & $\begin{array}{c}\text { Adults }(>18 \\
\text { years })(n=22)\end{array}$ \\
\hline age (years) & $\begin{array}{c}6-18 \\
(10.95 \pm 4.10)\end{array}$ & $\begin{array}{c}22-44 \\
(30.05 \pm 5.95)\end{array}$ \\
\hline BMI $\left(\mathrm{kg} / \mathrm{m}^{2}\right)$ & $23.86 \pm 5.53$ & $24.59 \pm 2.92$ \\
\hline
\end{tabular}

Table (3): Comparison of BMI, serum leptin, MDA and lipid profile indices levels between the epileptic patients and the controls.

\begin{tabular}{|l|c|c|c|c|}
\hline \multirow{2}{*}{$\begin{array}{c}\text { Parameters } \\
\text { Mean } \pm \text { SD }\end{array}$} & \multicolumn{2}{|c|}{ Children $(\leq 18 \mathrm{yrs})(\mathrm{n}=22)$} & \multicolumn{2}{c|}{ Adults $(>18 \mathrm{yrs})(\mathrm{n}=22)$} \\
\cline { 2 - 5 } & Epileptic children & Controls & Epileptic adults & Controls \\
\hline $\mathrm{BMI}\left(\mathrm{kg} / \mathrm{m}^{2}\right)$ & $27.75 \pm 4.41^{* *}$ & $23.86 \pm 3.53$ & $28.66 \pm 3.31^{* *}$ & $24.59 \pm 2.92$ \\
\hline Leptin $(\mathrm{ng} / \mathrm{ml})$ & $6.06 \pm 5.54^{* *}$ & $2.89 \pm 1.71$ & $9.81 \pm 5.38^{* *}$ & $3.91 \pm 1.96$ \\
\hline $\mathrm{MDA}(\mu \mathrm{Mol} / \mathrm{L})$ & $2.03 \pm 0.44^{* *}$ & $1.26 \pm 0.48$ & $2.06 \pm 0.51^{* *}$ & $0.95 \pm 0.22$ \\
\hline $\mathrm{TC}(\mathrm{mmol} / \mathrm{L})$ & $4.46 \pm 0.78$ & $4.48 \pm 0.79$ & $4.54 \pm 0.52$ & $4.66 \pm 0.71$ \\
\hline $\mathrm{TGs}(\mathrm{mmol} / \mathrm{L})$ & $1.44 \pm 0.45$ & $1.36 \pm 0.48$ & $1.34 \pm 0.44$ & $1.29 \pm 0.39$ \\
\hline $\mathrm{LDL}-\mathrm{m}(\mathrm{mmol} / \mathrm{L})$ & $3.01 \pm 0.83$ & $2.84 \pm 0.57$ & $3.18 \pm 0.62$ & $3.16 \pm 0.71$ \\
\hline $\mathrm{HDL}-\mathrm{c}(\mathrm{mmol} / \mathrm{L})$ & $0.79 \pm 0.13^{* *}$ & $1.02 \pm 0.27$ & $0.75 \pm 0.11^{* *}$ & $0.93 \pm 0.15$ \\
\hline $\mathrm{Al}$ & $5.64 \pm 1.50^{* *}$ & $4.55 \pm 0.77$ & $6.07 \pm 1.51^{* *}$ & $5.11 \pm 1.11$ \\
\hline
\end{tabular}

**: significant differences $p<0.001$. 


\section{Discussion}

The current study demonstrated higher body weight and significant increase in BMI in both children and adult epileptics on VPA therapy. Clinically significant weight gain has been reported with several AEDs including the conventional agents VPA, carbamazepine (CBZ) and the newer medications gabapentin and vigabatrin and may result in lack of compliance with or discontinuation of therapy (22). Among all of the AEDs, VPA a broadspectrum antiepileptic drug commonly used to treat children with focal and generalized epilepsy, has been the best studied with respect to effects on body weight ${ }^{(23)}$. Its etiology is most likely multi-factorial and controversial. Pylvanen et al. ${ }^{(24)}$ reported that $52 \%$ of men treated with VPA had BMI scores within the obesity category. Numerous pooled and specifically assigned data from clinical trials plus retrospective and cross-sectional analysis also reported that treatment with VPA is associated with a significant weight gain in $3-71 \%$ of patients which ranged from 5 to 49 $\mathrm{kg}^{(25,26)}$. In agreement with our results the study of Rauchenzauner et al., (27) who reported that long-term therapy with VPA in childhood was associated with significant increase in body weight, as well as Hamed et al., ${ }^{(28)}$ who also concluded that BMI was significantly elevated in VPA treated epileptic children compared with controls, untreated and those treated with other AEDs.

Several mechanisms have been suggested to explain VPA-related weight gain including:

1- The effect on the hypothalamus: this is supported by the observation that epileptic patients treated with VPA and reported weight gain also developed increased appetite thirst, and quenching with calorierich beverages ${ }^{(23)}$, all of which indicate hypothalamic stimulation ${ }^{(29)}$.

2- VPA-induced hyperinsulinemia and insulin resistance: this is supported by the observation that weight gain during VPA treatment is related to increase in insulin concurrent with decrease in glucose level which can stimulate appetite and may cause weight gain ${ }^{(23)}$.
3- VPA-induced hyperleptinemia and leptin resistance: this is supported by the observation that women who became obese after VPA therapy reported high leptin levels and insulin resistance while patients who remained lean did not show any changes ${ }^{(2)}$.

4- VPA-induced changes in circulating levels of leptin and its relation to ghrelin and adiponectin: this is supported by the observation that weight gain in VPAtreated patients was associated with increased concentrations of leptin and decreased concentrations of ghrelin and adiponectin. These changes were correlated with the extent of body weight, patients' BMI, the amount of adipose tissue and fasting plasma levels of insulin and leptin ${ }^{(30)}$. The down-regulation of ghrelin is considered as a consequence of increased insulin or leptin.

5- Genetic susceptibility to develop hyperleptinemia: this is supported by the observation that VPA-treated patients may manifest high serum leptin levels without weight gain and leptin level is correlated to $\mathrm{BMI}^{(31)}$.

The results of the current study also revealed an elevated serum leptin in both epileptic adults and children on VPA monotherapy. This is consistent with the finding of Rauchenzauner et al., ${ }^{(27)}$ and Hamed et al., ${ }^{(28)}$, both reported an increase in serum leptin in epileptic patients on continuous VPA therapy and that hyperleptinemia was common among epileptic children who gained weight with VPA therapy suggesting a state of leptin resistance. The mechanism of hyperleptinemia and leptin resistance with VPA treatment is still controversial. The increase in serum leptin levels in VPA-induced weight gain may be a consequence of increase in adipose tissue ${ }^{(4)}$. It has been suggested that VPA causes direct secretion of leptin from adipocytes.

Lipid peroxidation is an indicator of free radical metabolism and oxidative stress in human beings and other organisms. Malondialdehyde (MDA), is an end product of lipid peroxidation that can react with thiobarbituric acid. The estimation of MDA is a 
sensitive measure of lipid peroxidation ${ }^{(32)}$. This study revealed a significatly higher serum MDA in both epileptic children and adults receiving VPA monotherapy. In agreement with our finding, is the study conducted by Yukset et al ${ }^{(33)}$. They concluded that epileptic patients on VPA had an increased lipid peroxidation levels. Consistent with our results, also the study conducted by Solowiej and Solaniec ${ }^{(34)}$ who reported that the concentration of MDA was elevated in all epileptic patients significantly in both VPA monotherapy and polytherapy, while insignificant elevation was noticed in newly diagnosed epileptics and in CBZ monotherapy group. In their more recent research, Sobaniec et al., ${ }^{(35)}$, and Yiş et al ., ${ }^{(6)}$ both reported insignificant elevation in MDA concentration in epileptics on VPA monotherapy. While in contrast to our results, Peker et al.., ${ }^{(36)}$ who investigated the effects of VPA on lipid peroxidation among other parameters, reported no significant differences in serum MDA in comparison to healthy controls. In explanation to our results, there were several studies suggesting that excessive generation of free radical intermediates are associated with VPA administration possibly as a consequence of VPA biotransformation ${ }^{(37)}$, or alterations in glutathione homeostasis ${ }^{(38)}$ and lor depletion of cofactors required for antioxidant defense ${ }^{(9)}$.

The effect of VPA on lipid profile remains unclear. VPA has been reported to be associated with a decrease of serum LDL-c or TC ${ }^{(39,40)}$ and increased HDL-C ${ }^{(8)}$. No significant changes in serum lipid has been reported by others ${ }^{(13,41)}$. Our study revealed a significantly lower HDL-c and a highly significant increase in A.I in epileptic children on VPA monotherapy in comparison to healthy controls. In agreement with our results, is the study conducted by Zeitlhofer et al., ${ }^{(42)}$. They reported that VPA-treated epileptic patients showed decreased HDL-c levels. Eiris et al., ${ }^{(43)}$, also reported that epileptic children receiving continuous VPA monotherapy had significantly lower HDL-c than their matched control subjects. While in contrast to our results, Heldemberg et al.. ${ }^{(40)}$, reported that epileptic children receiving continuous VPA monotherapy had increased serum HDL-c.

This study also revealed insignificant differences in TC,TG and LDL-C in epileptic children on continuous VPA monotherapy which is in concordance with the results of Luef etal., ${ }^{(44)}$, who found insignificant differences in serum TC,TG and LDL-C between epileptic children receiving continuous VPA monotherapy and their matched controls. Furthermore, this study also demonstrated that epileptic adults receiving continuous VPA monotherapy had significantly lower HDL-C and significantly higher Al than their matched controls. This is consistent with the results of the study conducted by Hamed et al., ${ }^{(28)}$. They reported that epileptic adults on continuous VPA monotherapy had significantly lower HDL-c than their matched controls.

In conclusion., VPA monotherapy in epileptic children and adults can cause a rise in BMI, serum leptin and MDA ( as a reflection of oxidative stress) and also causes a significant reduction in HDL-C and a significant rise in Al which needs further evaluation with larger number of patients.

\section{References}

1. Isojärvi JIT, Tauboll E, Tapanainen JS, Pakarinen AJ, Laatikainen TJ, Knip M and Myllyla VV. The association between sodium valproate and polycystic ovary syndrome: a response and an alternative view. Epilepsia 2001; 42: 305310.

2. Verrotti $A$, Basciani $F$, De Simone $M$, Trotta D, Morgese $G$ and Chiarelli $F$. Insulin resistance in epileptic girls who gain weight after therapy with valproic acid. J Child Neurol 2002; 17: 265-268.

3. Sheth R. Adolescent issues in epilepsy. J Child Neurol 2002; 17 (I2): 23-27.

4. Lagace DC, Mcleod RS and Nachtigal MW. Valproic acid inhibits leptin secretion and reduces leptin messenger ribonucleic acid levels in adipocytes. Endocrinol 2004; 145(12): 5493-5503.

5. Aydin K, Serdaroglu A, Okuyaz C, Bidect $S$ and Gucuyener K. Serum insulin, leptin, and neuropeptide $Y$ levels in epileptic 
children treated with sodium valproate. $\mathrm{J}$ Child Neurol 2005; 20: 848-851.

6. Yiş $U$, Seckin E, Kurul SH, Kuralay $F$ and Dirik E. Effects of epilepsy and valproic acid on oxidant status in children with idiopathic epilepsy. Epilepsy Res 2009; 84(2-3): 232-237.

7. Maertens P, Dyken P, Graf W, Pippenger $C$, Chronister $R$ and Shah A. Free radicals, anticonvulsants and the neuronal ceroid lipofuscinosis. Am J Med Genetics 1995; 57: 225-228.

8. Yuksel $A$, Cengiz $M$, Seven $M$ and Ulutin T. Erythrocyte glutathione, glutathione peroxidase, superoxide dismutase and serum lipid peroxidation in epileptic children with sodium valproate and carbamzepine monotherapy. J Basic Clin Pharmacol 2000; 11: 73-81.

9. Graf WD, Oleinik OE, Glauser TA, Maertens P, Eder DN and Pippenger CE. Altered antioxidant activities in children with a serious side adverse experience related to valproic acid therapy. Neuropediatr 1996; 29: 195-201.

10. Yalcin E, Hassanzadeh A and Mawlud K. The effects of long-term anticonvulsive treatment on serum lipid profile. Acta Pediatr Jap 1997; 39: 342-345.

11. Sudhop T, Bauer J, Elger CE and Von Bergmann K. Increased high-density lipoprotein cholesterol in patients with epilepsy treated with carbamazepine: a gender-related study. Epilepsia 1999; 40: 480-484.

12. Ayanci FM, Orhan F, Örem A,Yildirmis $S$ and Geddik Y. Effect of antiepileptic drugs on plasma lipoprotein (a) and other lipid levels in childhood. J Child Neurol 2001; 16: 367-369.

13. Yilmaz E, Dosan $Y$, Gurgoze $M K$ and Gungor S. Serum lipid changes during anticonvulsive treatment serum lipids in epileptic children. Acta Neuro Belg 2001; 101: 217-220.

14. Buege JA and Aust SD. Thiobarbituric acid assay. Methods Enzymol 1978; 52: 306307.

15. Allain CC, Poon LS, Chan CS, Richmond $\mathrm{W}$ and Fu PC. Determination of serum total cholesterol by the enzymatic colorimetric method. Clin Chem 1974;20(4): 470-475.

16. Lopez-Virella MF, Stone $P$, Ellis $S$ and GIwell JA. Cholesterol determination in high density lipoprotein separated by three different methods. Clin Chem 1977;23: 882-884.

17. Friedewald WT, Levy RJ and Fredrickson DS. Estimation of the concentration of LDL-C in plasma without use of the preparative ultracentrifuge. Clin Chem 1972; 18: 499-502.

18. Walsh BW, Schiff I and Rosner B. Effects of postmenopausal estrogen replacement in the case of Metabolism and plasma lipoprotein. N Eng J Med 1991; 325: 11961204.

19. Leermarkers EA, Dunn AL and Blair SN. Exercise management of obesity. Medical Clinics of North America 2000;84:419-425.

20. Kuczmarski RJ, Ogden CL, grummerStraw LM, Flagal KM, Guo SS and Wei R et al. CDC growth charts: United States. Adv Data 2000;8:1-27.

21. Kirkwood BR. Essentials of Medical Statistics. $1^{\text {st }}$ ed., Blackwell Scientific Publication, Oxford 1988.p:43-56.

22. Biton V. Effect of antiepileptic drugs on body weight. Overview and clinical implications for the treatment of epilepsy. CNS Drugs 2003; 17(11): 781-791.

23. Demir $E$ and Aysun S. Weight gain associated with valproate in childhood. Pediatr Neurol 2000; 22: 361-364.

24. Pylvanen V, Knip M, Pakarinen A, Kotila $\mathrm{M}$, Turkka $\mathrm{J}$ and Isojarvi $\mathrm{JI}$. Serum insulin and leptin levels in sodium valproate associated obesity. Epilepsia 2002; 43: 514-517.

25. Biton V, Levisohn $P$, Hoyler S, Vuong A and Hammer AE. Lamotrigine versus valproate monotherapy associated weight changes in adolescents with epilepsy: results from a post hoc analysis of a randomized, double-blind trial. J Child Neurol 2003;18: 133-139.

26. Zimmermann $U$, Kraus $T$; Himmerich $H$, Schuld A and Pollmacher T. Epidemiology, implications and mechanisms underlying 
drug-induced weight gain in psychiatric patients. J Psychiatr Res 2003; 37: 193220.

27. Rauchenzauner M, Haberlandt E, SchollBurgi S, Ernst B, Hoppchler F, Karall D, et al. Adiponectin and visfatin concentrations in children treated with valproic acid. Epilepsia 2008; 49(2):353-357.

28. Hamed SA, Fida NM, Hamed EA. States of serum letin and insulin in children with epilepsy. Risk predictors of weight gain. Euro J Pediatr Neurol 2009; 13: 261-268.

29. Breum L, Astrup A, Gram L, Andersen T, Stokholm KH, Christensen $\mathrm{NJ}$, et al. Metabolic changes during treatment with valproate in humans: implication for untoward weight gain. Metabol 1992; 41: 666-670.

30. Greco R, Latini G, Chiarelli F, Lannetti P and Verrotti A. Leptin, ghrelin and adiponectin in epileptic patients treated with valproic acid. Neurol 2005;65:18081809.

31. Verrotti A, Basciani F, Morresi S, Martino M, Morgese G, Chiarelli F. Serum changes in epileptic patients who gain weight after therapy with valproic acid.Neurol 1999;53:230-232.

32. Deepa D, Jayakumari B, Thomas SV. Lipid peroxidation in women with epilepsy. Ann Indian Acad Neurol 2008;11(1):44-46.

33. Yuksel A, Cengiz M, Seven M, Ulutin T. Changes in the antioxidant system in epileptic children receiving antiepileptic drugs: Two years prospective studies. J Child Neurol 2001;16:603-606.

34. Solowiej E, Sobaniec W. The effect of antiepileptic drug therapy on antioxidant enzyme activity and serum lipid peroxidation in young patients with epilepsy. Neurol Neurochir Pol 2003; 37(5): 991-1003.

35. Sobaniec W, Solowiej E, Kulak W, Bockowski L, Smigielska-Kuzia J, Artemowicz B. Evaluation of the influence of antiepileptic therapy on antioxidant enzyme activity and lipid peroxidation in erythrocytes of children with epilepsy. J Child Neurol 2006;21(7):558-562.
36. Peker E, Oktar S, Ari M; Kozan R, Dogan $M$ and Çagan $E$ et al. Nitric oxide, lipid peroxidation, and antioxidant enzyme levels in epileptic children using valproic acid.Brain Res 2009;1297:194-197.

37. Jurima-Romet $M$, Abbott FS, Tang W, Huang HS and Whitehouse LW. Cytotoxicity of unsaturated metabolites of valproic acid and protection by vitamin $\mathrm{C}$ and $E$ in glutathione- depleted rat hepatocytes. Toxicol 1996;112(1):69-85.

38. Tong $\mathrm{V}$, Teng XW, Chang TKH and Abbott FS. Valproic acid I. Time course of lipid peroxidation biomarkers, liver toxicity and valproic acid metabolite levels in rats. Toxicol. Sci 2005;86(2):427-435.

39. Franzoni E, Descovich GC and Salvioli GP. Total cholesterol, high density lipoprotein and triglycerides in children receiving antiepileptic drugs. Epilepsia 1992; 33:932-935.

40. Heldenberg D, Harel S, Holtzman M, Levtow $O$ and Tamir I. The effect of chronic anticonvulsant therapy on serum lipids and lipoproteins in epileptic children. Neurol 1983;33:510-513.

41. Pita-Calandre E, Rodriguez-Lopez CM, Cano MD, Pena-Bernal M. Serum lipids, lipoproteins and apolipoproteins in adult epileptics treated with carbamazepine, valproic acid or phenytoin. Rev Neurol 1998;27(159):785-789.

42. Zeitlhofer J, Dopelbauer A, Tribl G, Leitha $T$, Deecke L. Changes of serum lipid patterns during long-term anticonvulsive treatment. Clin Investig 1993;71:574-578.

43. Eiris J, Novo-Podrigues $\mathrm{MI}$, Delrio $\mathrm{M}$, Meseguer P, Delrio MC, Castro-Gugo M. The effects on lipid and apolipoprotein serum levels of long-term carbamazepine, valproic acid and Phenobarbital therapy in children with epilepsy. Epilepsy Res 2000; 41:1-7.

44. Luef $G$, Rauchenzauner M, Waldmann M, Sturn W, Sandhofer A, Seppi K, etal. Nonalcoholic fatty liver disease ( NAFLD), insulin resistance and lipid profile in antiepileptic drug treatment. Epilepsy Res 2009;86:42-47. 